\title{
Perancangan Sistem Pengelolaan Limbah Durian Layak Kompos di Agrowisata Kampung Durian Ponorogo
}

\author{
Atika Rukminastiti Masrifah, Haris Setyaningrum, Adib Susilo, Imam Haryadi \\ University of Darussalam Gontor Ponorogo \\ E-mail: atikamasrifah@unida.gontor.ac.id; haris.setyaningrum@unida.gontor.ac.id; \\ adibsusilo@unida.gontor.ac.id; haryadi@unida.gontor.ac.id
}

\section{Article History: \\ Received: Aug 14th 2020 \\ Revised: Dec 17th 2020 \\ Accepted: May 30th 2021}

Keywords: Durian, Composter house, organic fertilizer

\begin{abstract}
Ngebel is known as one of the centers for durian fruit in Ponorogo, and is known as Kampung Durian. Durian skin waste that has not been utilized. Through the Asset Based Community Development (ABCD) approach the team of this community service has assisted to make use of durian skin waste to become organic fertilizer to supplements the durian crops. Through the construction of the composter house and technology transfer support program for the processing of durian skin waste into organic fertilizer, the results showed that the people of Kampung Durian village were able to make organic fertilizer with good quality standards. The organic fertilizer products have been tested on durian crops, so that they can increase the production and quality of durian fruit, increase the capacity of the Karang Asri Farmer Group in Kampung Durian to use local resources and increase the capacity to cultivate and process durian skin waste.
\end{abstract}

\section{Pendahuluan}

Kampung Durian Desa Ngrogung Kecamatan Ngebel Ponorogo merupakan tempat wisata kuliner bagi penggemar buah durian. Pengunjung dapat menikmati bermacammacam jenis durian, salah satunya durian Kanjeng. Potensi yang dimiliki masyarakat Desa Ngrogung ialah 68\% lahan di desa ini adalah berupa lahan perkebunan, 80\% nya merupakan kebun produksi durian, dan setiap tahunnya selalu ada peningkatan pengunjung penikmat buah durian rata-rata $20 \%{ }^{1}$.

1 BPS Kab. Ponorogo, Ponorogo Dalam Angka 2018. (Kab Ponorogo: BPS Kab Ponorogo, 2018), https://ponorogokab.bps.go.id/ publication/2018/08/16/7400511f763983ffbab97edf/kabupatenponorogo-dalam-angka-2018.html. 
Tabel 1. Sumber Daya Alam yang Dimiliki Kelompok Tani Desa Ngrogung

\begin{tabular}{c|c|c|c}
\hline \multicolumn{4}{c}{ Luas Lahan 700 Ha } \\
\hline Tanah Sawah & $\begin{array}{c}\text { Tanah } \\
\text { Pekarangan }\end{array}$ & Tanah Tegalan & Lainnya \\
\hline $35 \mathrm{Ha}$ & $475 \mathrm{Ha}$ & $190 \mathrm{Ha}$ & $100 \mathrm{Ha}$ \\
\hline \multicolumn{3}{c}{ Jumlah Pembibitan } \\
\hline \multicolumn{2}{c}{ Pohon Durian } & Pohon Manggis \\
\hline \multicolumn{2}{c}{5000 pohon } & 1000 pohon \\
\hline
\end{tabular}

Sumber: BPS Kab Ponorogo ${ }^{2}$

Menurut Bambang Subagyo (2020) selaku ketua Kelompok Tani Karang Asri yang merangkap ketua Pokdarwis desa Ngrogung mengatakan bahwa saat ini minat masyarakat terhadap durian kanjeng sangat banyak karena rasanya sangat lezat dan lembut. Pada hari libur biasanya Kampung Durian menyiapkan 500 hingga 600 buah durian dan terkadang kelompok tani tidak mampu untuk memenuhi demand pasar ${ }^{3}$.

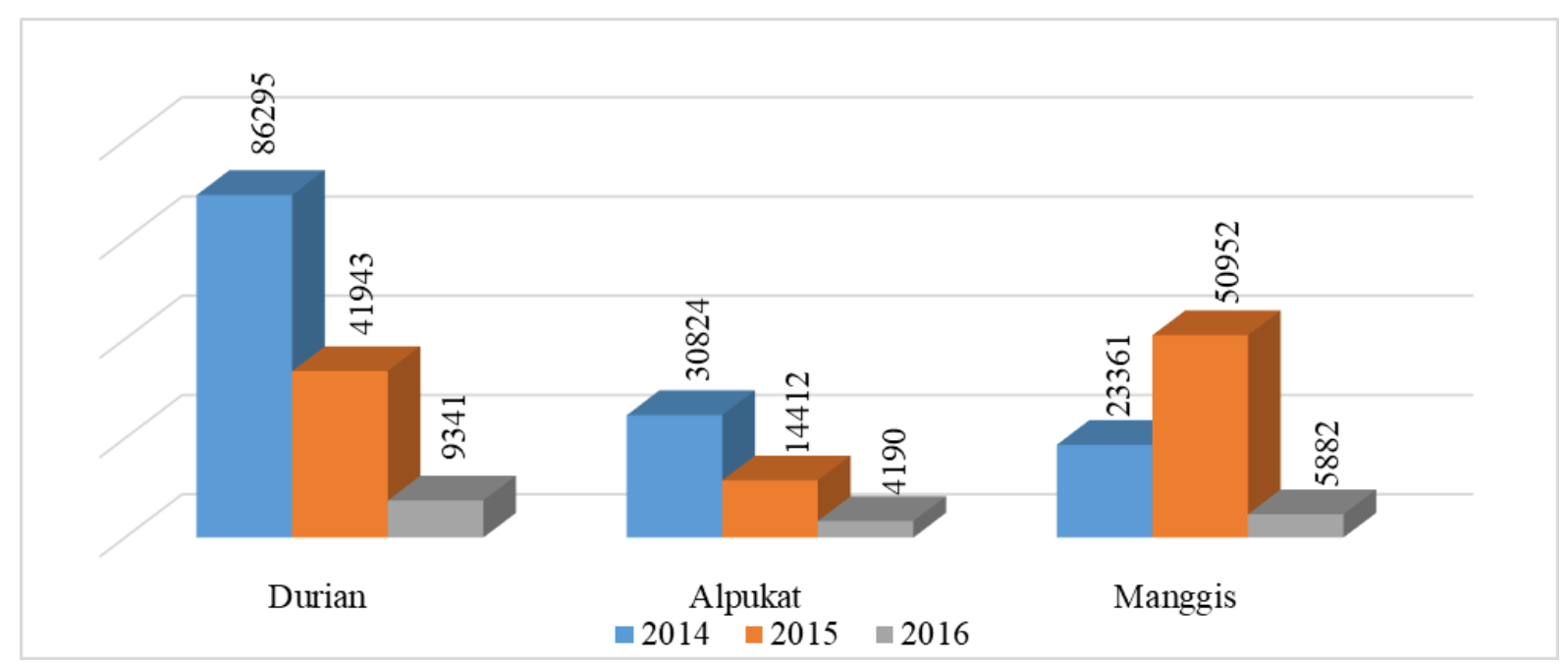

Gambar 1. Produksi Perkebunan Desa Ngrogung (dalam ton) Sumber: BPS Kab Ponorogo 4

Berdasarkan data di atas, rata-rata produksi buah durian mengalami penurunan sebesar 65\% selama tiga tahun (2014 - 2016), disandingkan dengan peningkatan pengunjung yang semakin bertambah tiap tahunnya, sehingga kelompok tani tidak mampu memenuhi demand pasar. Terjadinya kekurangan supply durian juga dapat disebabkan karena faktor alam dan beberapa faktor non alam. Faktor alam yang

2 BPS Kab. Ponorogo, Statistika Daerah Kecamatan Ngebel 2017 (Kab Ponorogo: BPS Kab Ponorogo, 2017).

3 Bambang Subagyo. Hasil Wawancara Ketua Kelompok Tani Karang Asri Ngrogung Ngebel Ponorogo. (2018). 2017).

4 BPS Kab. Ponorogo, Kecamatan Ngebel Dalam Angka 2017 (Kab Ponorogo: BPS Kab Ponorogo, 
menyebabkan menurunnya produksi durian ialah sulitnya akses air untuk pengairan perkebunan durian. Letak wilayah pegunungan di Desa Ngrogung sangat cocok untuk tanaman durian, memiliki tanah sangat subur namun pengairan lahan kering cukup sulit. Sekitar 5000 pohon durian mengalami kesulitan pengairan dan membutuhkan pemupukan secara tepat guna.

Sementara faktor non alam yang menyebabkan menurunnya produksi durian antara lain minimnya pengetahuan tentang pemupukan, pengobatan dan pengairan. Menyikapi terjadinya permasalahn tersebut, Kampung Durian mengembangkan dan menggalakkan penggunaan pupuk organik. Penggunaan pupuk organik dapat memperbaiki struktur tanah ${ }^{5}$, sehingga akan meningkatkan kesuburan pada lahan kebun dan memperbaiki kualitas buah.

Pupuk organik atau kompos yang direncanakan ialah kompos yang berasal dari limbah kulit durian itu sendiri. Hal ini akan menjadi solusi bagi permasalah masyarakat Desa Ngrogung, yaitu penumpukan limbah durian. Bambang Subagyo (2020) memaparkan bahwa dari $700 \mathrm{~kg}$ rata-rata produksi durian, diperoleh kulit durian sebesar 62,4\% dan menjadi limbah ${ }^{6}$.

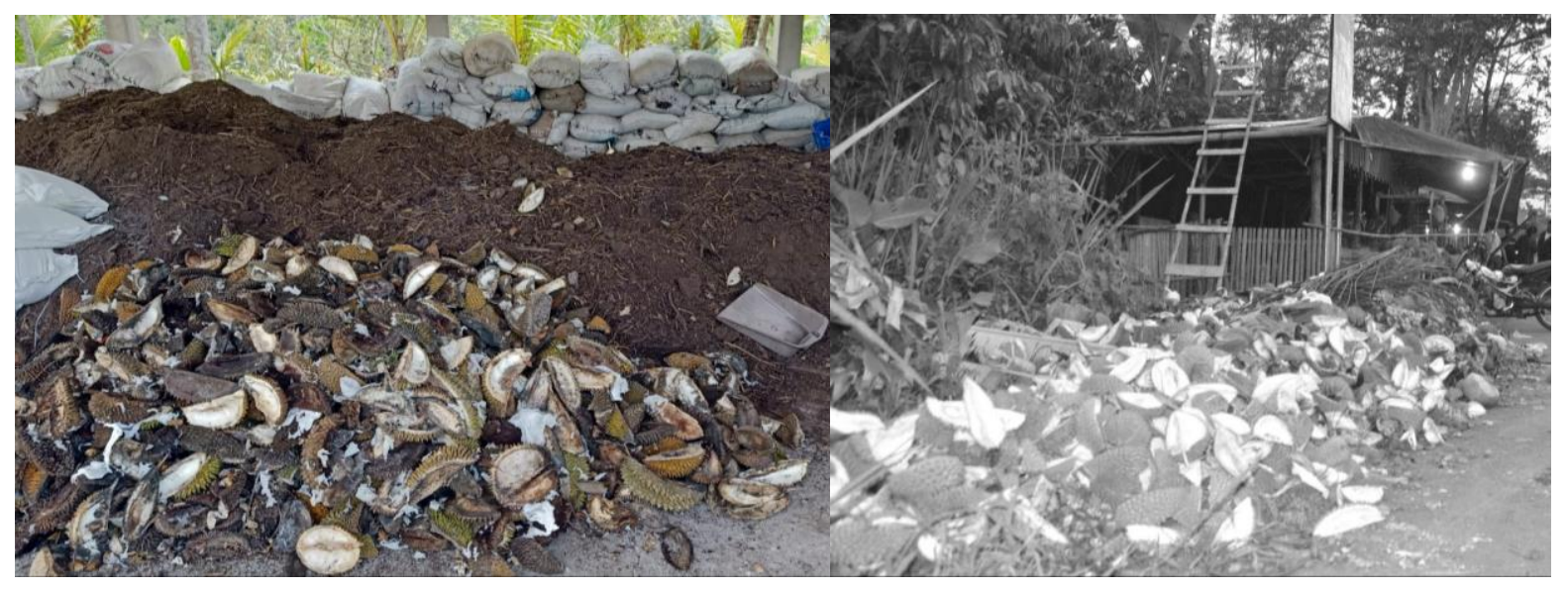

Gambar 2. Limbah Kulit Durian Menumpuk

Salah satu sisi negatif dari kawasan penghasil buah durian di Ponorogo adalah volume sampah kulit durian yang menumpuk. Hal ini disebabkan karena sebagian besar pengunjung dan masyarakat sekitar, termasuk para pedagang dan pengkonsumsi durian, membuang kulit durian begitu saja. Limbah kulit durian tersebut jika tidak dikelola secara baik dan bermanfaat, maka akan menimbulkan masalah bagi lingkungan, menimbulkan bau yang tidak sedap dan menjadikan lingkungan kotor.

5 Volmer Damanik, Lahuddin Musa, and Posma Marbun, "Pengaruh Pemberian Kompos Kulit Durian Dan Kompos Kulit Kakao Pada Ultisol Terhadap Beberapa Aspek Kimia Kesuburan Tanah," Jurnal Agroekoteknologi Universitas Sumatera Utara 2, no. 1 (2013): 97671.

6 Bambang Subagyo. Hasil Wawancara Ketua Kelompok Tani Karang Asri Ngrogung Ngebel Ponorogo. (2020). 
Pupuk organik yang berasal dari bagian tumbuhan itu sendiri ${ }^{7}$, dalam hal ini mengembalikan limbah kulit durian itu sendiri ke dalam lapisan olah tanah (top soil) ${ }^{8}$ sebagai bahan organik dalam bentuk yang telah dikomposkan berperan penting dalam perbaikan sifat kimia, fisika dan biologi tanah serta sebagai sumber nutrisi tanaman durian ${ }^{9}$. Upaya tim pengabdian masyarakat untuk mendukung kelompok tani Karang Asri dalam kemandirian mengembangkan pupuk organik adalah dengan memfasilitasi kegiatan pengembangan penggunaan mesin pengolah limbah kulit durian menjadi kompos dan disertai dengan pembangunan rumah kompos ${ }^{10}$.

Berangkat dari kondisi di atas, maka Tim melakukan pendampingan kelompok tani Karang Asri Kampung Durian agar mereka memiliki kemampuan untuk mengelola limbah kulit durian yang tidak dimanfaatkan menjadi pupuk kompos sehingga memiliki manfaat untuk mereduksi timbunan sampah kulit durian di kawasan Ngebel dan sekitar Ponorogo. Pendampingan ini juga memiliki manfaat untuk menyediakan fasilitas terpadu pengolahan pupuk kompos di Kampung Durian Ponorogo.

\section{Metode}

Salah satu metode untuk merubah kondisi lingkungan masyarakat yang sesuai harapan yaitu dengan memberikan pendampingan pembuatan pupuk kompos dari limbah buah durian melalui pendekatan ABCD (Asset Based Community Development). Pendekatan berbasis aset ini ditemukan oleh John McKnight dan Jody Kretzmann ${ }^{11}$. Keduanya melakukan penelitian mengenai karakteristik inisatif komunitas. Pada awalnya, pendekatan ini dijadikan sebagai pendekatan alternatif atas pembangunan yang berbasis kebutuhan. Kemudian terciptalah sebuah pendekatan untuk memajukan kesejahteraan komunitas. Pendekatan tersebut disebut Pendekatan Berbasis Aset (AssetBased Community Development/ABCD).

Melalui pendekatan ABCD, tim melakukan pendampingan agar komunitas memiliki kemampuan dalam perubahan sosial (social transformation) ${ }^{12}$ berdasarkan

${ }^{7}$ Rosliana Lubis, Basuki Wirjosentono, and Amanda Septevani, "Extraction and Characterization of Cellulose Fiber of Durian Rinds from North Sumatera as the Raw Material for Textile Fiber," in Journal of Physics: Conference Series, vol. 1232 (IOP Publishing, 2019), 12017.

8 Patpen Penjumras et al., "Extraction and Characterization of Cellulose from Durian Rind," Agriculture and Agricultural Science Procedia 2 (2014): 237-243.

${ }^{9}$ Khoiron Khoiron et al., "A Review of Environmental Health Impact from Municipal Solid Waste (MSW) Landfill," Annals of tropical medicine and public health 23, no. 3 (2020): 60-67.

${ }^{10}$ Haris Setyaningrum et al., "Durian Rind Micro Composter Model: A Case of Kampung Durian, Ngrogung, Ponorogo, Indonesia," in E3S Web of Conferences, vol. 226 (EDP Sciences, 2021), 21.

11 John McKnight, “Asset-Based Community Development: The Essentials," Chicago: Asset-Based Community Development Institute (2017).

12 Alison Mathie and Gord Cunningham, "From Clients to Citizens: Asset-Based Community Development as a Strategy for Community-Driven Development," Development in practice 13, no. 5 (2003): 
dari kemampuan yang dimiliki oleh Kelompok Tani Karang Asri. Tim berlaku sebagai fasilitator yang menjembatani kelompok tani untuk mengenali potensi kelompok tani, sehingga mereka bisa mengembangkan pengetahuan dan membuat perubahan dengan memiliki kemampuan pengolahan dari hasil produk yang mereka hasilkan. Produk yang mereka hasilkan nantinya dapat dimanfaatkan dengan dengan baik dari kulit durian menjadi pupuk kompos yang bermanfaat bagi kelompok tani Karang Asri dan Desa Ngrogung secara umum.

Ada beberapa tahapan yang dilakukan oleh Tim dalam melakukan pendampingan ini, diantaranya, tahap inkulturasi, discovery, design, define, dan refleksi ${ }^{13}$. Pada tahap inkulturasi, tim melakukan pendekatan untuk mengenal lebih dekat kelompok tani Karang Asri. Pada tahapan selanjutnya, discovery, tim melakukan pemetaan asset dan potensi petani durian yang tergabung dalam kelomok tani dibawah naungan Kampung Durian. Setelah mengetahui potensi yang dimiliki, tahap design, define dan refleksi dilakukan oleh tim untuk mengidentifikasi berbagai peluang dari potensi dan asset, serta penetapan dan implementasi program kerja bagi kelompok tani Karang Asri di Desa Ngrogung Ponorogo. Metode ABCD ini dijalankan dalam rangka pengembangan teknologi pengolahan kompos limbah durian, guna alih teknologi dalam budidaya durian untuk meningkatkan produksi dan kualitasnya.

\section{Hasil}

Pendekatan berbasis kebutuhan berfokus pada apa yang dibutuhkan kelompok tani, kekurangan dan masalahnya. Pada tahap petama, inkulturasi dan discovery. Tim melakukan identifikasi masalah dan kebutuhan kelompok tani, kemudian menggali prestasi kelompok tani di masa lalu serta apa yang mereka telah lakukan di saat ini.

Tim melakukan kunjungan dan observasi di Kampung Durian Ngrogung Ponorogo. Tim juga melakukan komunikasi dengan para petani yang tergabung dalam Kelompok Tani Karang Asri, penelusuran komunitas melalui berita, serta berbagai langkah lainnya, sehingga Tim mengenal lebih dekat kelompok tani yang akan menjadi mitra dampingan kegiatan pengabdian ini.

Hasil tahap ini menunjukkan bahwa Kampung Durian memiliki segmen pasar dan daya jual yang kuat. Hasil produk Kampung Durian, utamanya Durian Kanjeng, salah satu produk unggulan daeran tersebut, telah dikenal masyarakat luas, baik dari Pemerintah Daerah bahkan Pemerintah Pusat, termasuk Kementrian Pertanian

474-486.

13 Wiwik Handayani and Sinta Dewi, "Pendampingan Pembuatan Pakan Ternak Dari Limbah Pembungkus Lontong Untuk Peningkatan Ekonomi Masyarakat Di Kelurahan Kupang Krajan Kecamatan Sawahan Kota Surabaya," Engagement: Jurnal Pengabdian Kepada Masyarakat 4, no. 2 (2020): 551-562. 
Salah satu sisi negatif dari kawasan penghasil buah durian di Ponorogo adalah volume sampah kulit durian yang menumpuk. Hal ini disebabkan karena sebagian besar pengunjung dan masyarakat sekitar, termasuk para pedagang dan pengkonsumsi durian, membuang kulit durian begitu saja.

Limbah kulit durian tersebut jika tidak dikelola secara baik dan bermanfaat, maka akan menimbulkan masalah bagi lingkungan, menimbulkan bau yang tidak sedap dan menjadikan lingkungan kotor ${ }^{14}$. Untuk mengatasi masalah tersebut, perlu adanya inovasi dalam pengelolaan sampah kulit durian dengan melibatkan masyarakat luas sehingga sampah kulit durian dapat dimanfaatkan menjadi produk yang bernilai ekonomis.

Berangkat dari realitas tersebut, maka Tim pendamping melakukan tahapan design dan define melalui kegiatan antara lain sebagai berikut: (1) Organizational Mapping, yakni mengidentifikasi kapasitas kelompok tani untuk memotret "energy" petani durian; (2) Individual Inventory Skill, yaitu melakukan individual asset dengan menggunakan interview dan focus group discussion (FGD) dengan kelompok tani; (3) Leaky Bucket; dengan mengenali, mengidentifikasi dan menganalisa aktivitas dan perputaran keluar masuknya ekonomi para petani Durian; serta (4) Low Hanging Fruit yang digunakan dalam menentukan keinginan dan harapan petani yang tergabung dalam kelompok tani berdasarkan potensi dan asset yang dimiliki oleh mereka sendiri tanpa ada bantuan dari pihak luar.

Hasil tahap design dan define ini, Tim telah melakukan FGD dengan kelompok tani dan beberapa warga Desa Ngrogung. Mereka menyadari bahwa hasil perkebunan durian mereka sudah sangat membantu perkenomian keluarga mereka. Di sisi lain, limbah buah durian yang sangat berlimpah di wilayah mereka belum bisa diolah dan dimanfaatkan secara maksimal, sehingga memberikan beban tambahan timbulan sampah di sekitar wilayah pariwisata Ngebel Ponorogo.

Oleh karena itu, gagasan untuk mengolah limbah durian menjadi pupuk kompos dipandang menjadi salah satu solusi yang baik untuk mengurangi beban timbulan sampah, sekaligus memberikan nilai tambah untuk meringankan para petani dalam bentuk pupuk organik, yang nantinya akan menjadi pupuk utama di perkebunan durian milik kelompok tani tersebut, bahkanpetani durian yang ada di Ponorogo.

Tim pendamping membantu mendesain arsitektur bangunan yang mereka butuhkan. Pengolahan limbah durian tersebut membutuhkan tempat khusus yang disebut rumah kompos dan model terintegrasi pengolahan limbah kulit durian ${ }^{15}$. Rumah

14 Ratna Dewi Kusumaningtyas, Hardi Suyitno, and Ria Wulansarie, "Pengolahan Limbah Kulit Durian Di Wilayah Gunungpati Menjadi Biopestisida Yang Ramah Lingkungan," Rekayasa: Jurnal Penerapan Teknologi dan Pembelajaran 15, no. 1 (2018): 38-43.

15 Bag Kinantan, A Rahim Matondang, and Juliza Hidayati, “Design of Integrated Waste Management Model of Medan City With Dynamic System Approach," in IOP Conference Series: Materials Science and Engineering, vol. 505 (IOP Publishing, 2019), 12106. 
kompos yang akan dibangun memiliki konstruksi sebagai berikut:

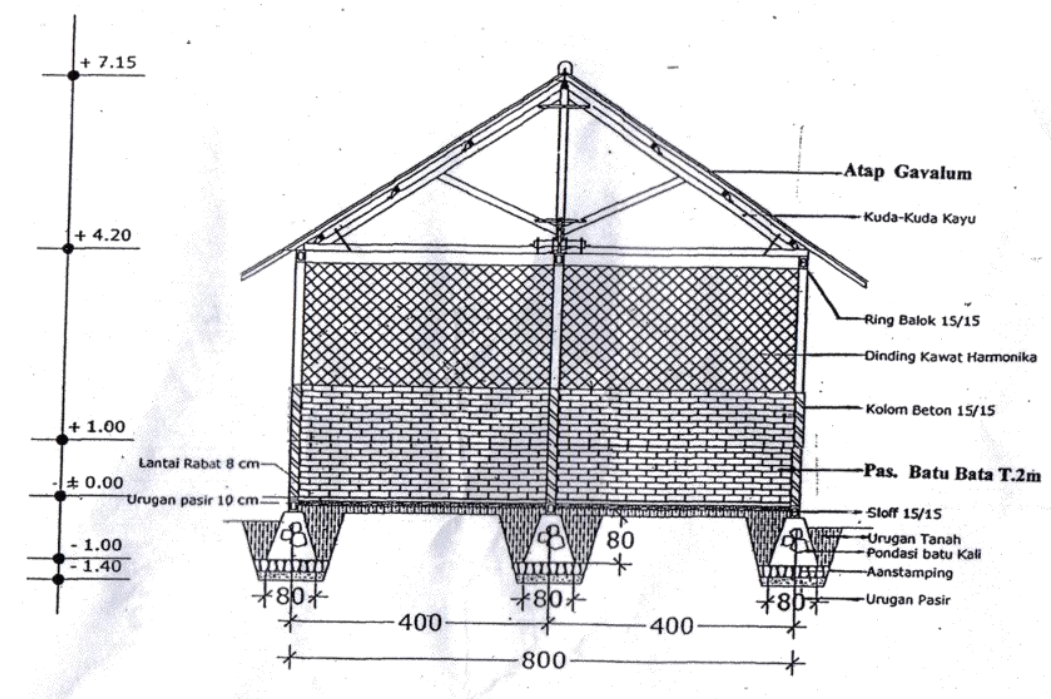

Gambar 4. Konstruksi Rumah Kompos Kampung Durian

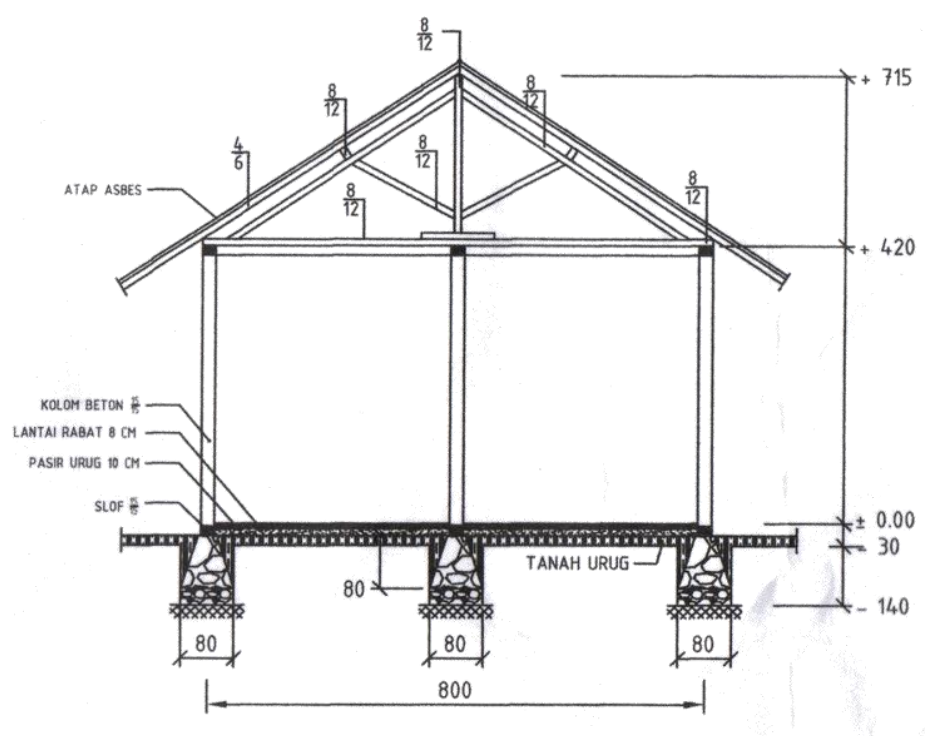

Gambar 5. Denah Rumah Kompos Kampung Durian

Kontruksi rumah kompos terdiri dari luas bangunan $152 \mathrm{~m}^{2}$ yaitu $19 \mathrm{~m}$ x 8m, luas kebun durian 15 ha dan luas tempat fermentasi $20 \mathrm{~m}^{2}$, tersebar di seluruh kebun durian menggunakan drum plastik. Bangunan rumah kompos terdiri dari gudang dan jogo semi outdoor, kemudian memiliki bak fermentasi pupuk cair yang berada di luar bangunan rumah kompos. Selain itu, pendampingan juga dilakukan dalam pengadaan peralatan dan mesin yang mengacu kepada spesifikasi teknis sebagai berikut: alat pengolah pupuk organik dengan kapasitas: minimal $1.000 \mathrm{~kg} / \mathrm{jam}$, bahan pisau yang terbuat dari baja kekerasan minimal 54 hcr, berfungsi sebagai pencacah, penghancur dan menghaluskan 
kulit durian, mesin penggerak 16 pk, yang memiliki Standar Nasional Indonesia (SNI) dan memiliki test report dari instansi yang berwenang, serta flower sprayer.

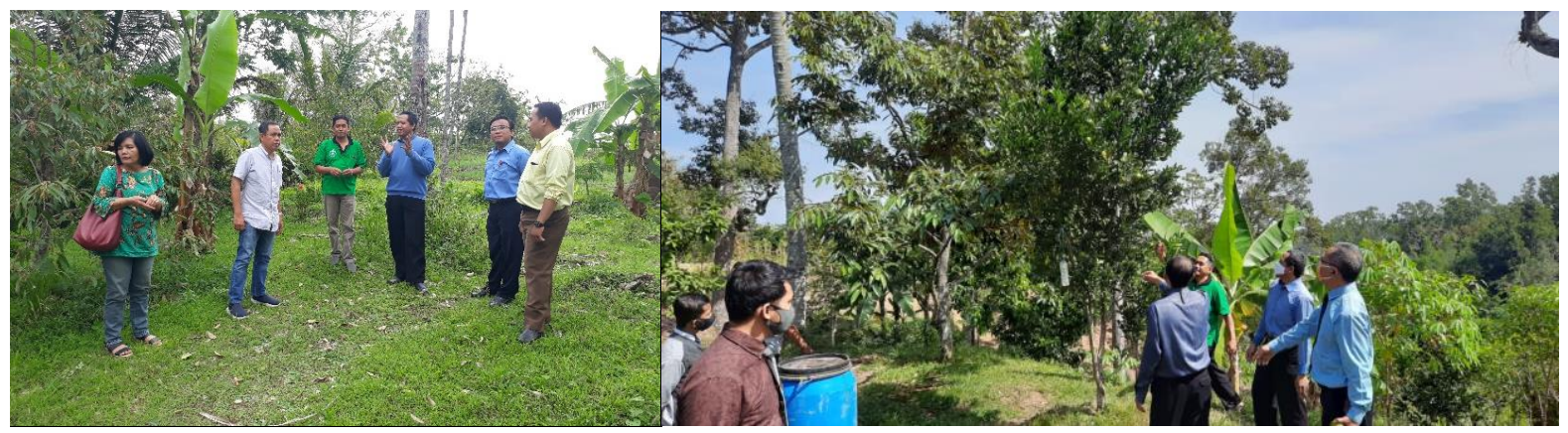

Gambar 6. Tim Asesor Meninjau Lokasi Bakal Pembangunan Rumah Kompos

Pembanguanan rumah kompos Kampung Durian tidak lepas dari peran para anggota kelompok tani Karang Asri. 35 orang yang tergabung dalam kelompok tani ini bergotong-royong untuk menyelesaikan pembanguan rumah kompos dalam waktu yang singkat. Harga upah tukang (pekerja) untuk membangun rumah kompos Kampung Durian merupakan upaya yang dilakukan Kelompok Tani dalam mendukung kegiatan pengabdian masyarakat ini.

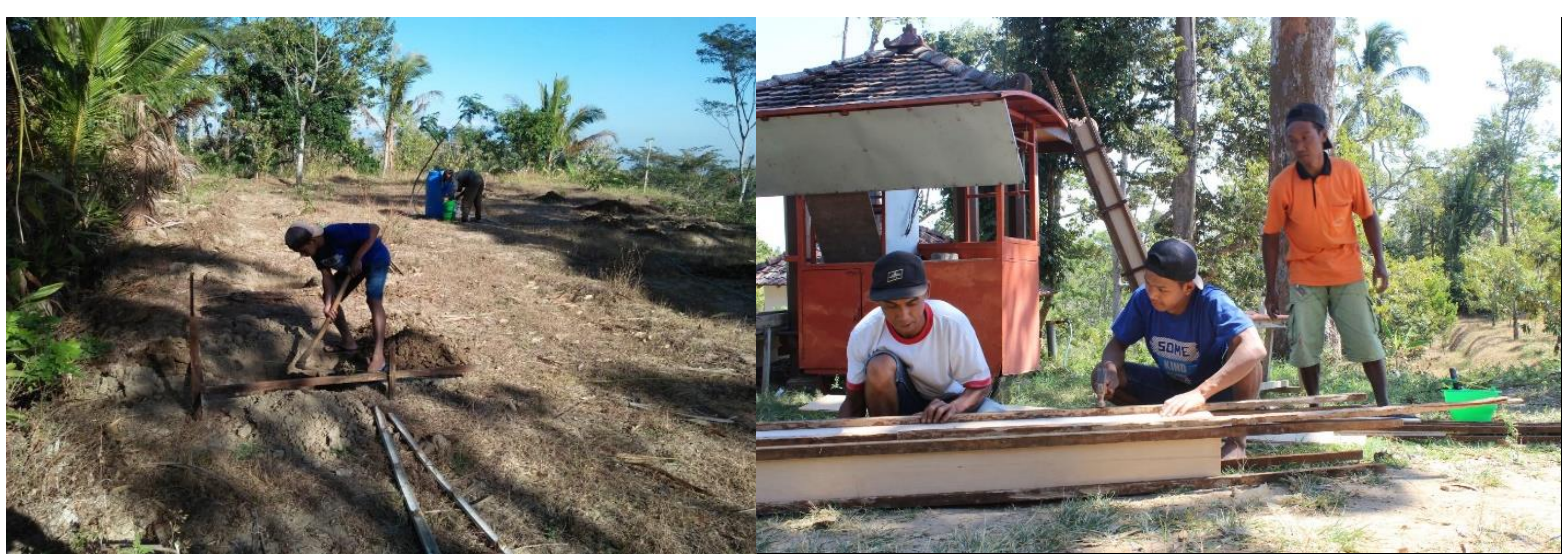

Gambar 7. Kelompok Tani Gotong Royong dalam Pembangunan Rumah Kompos

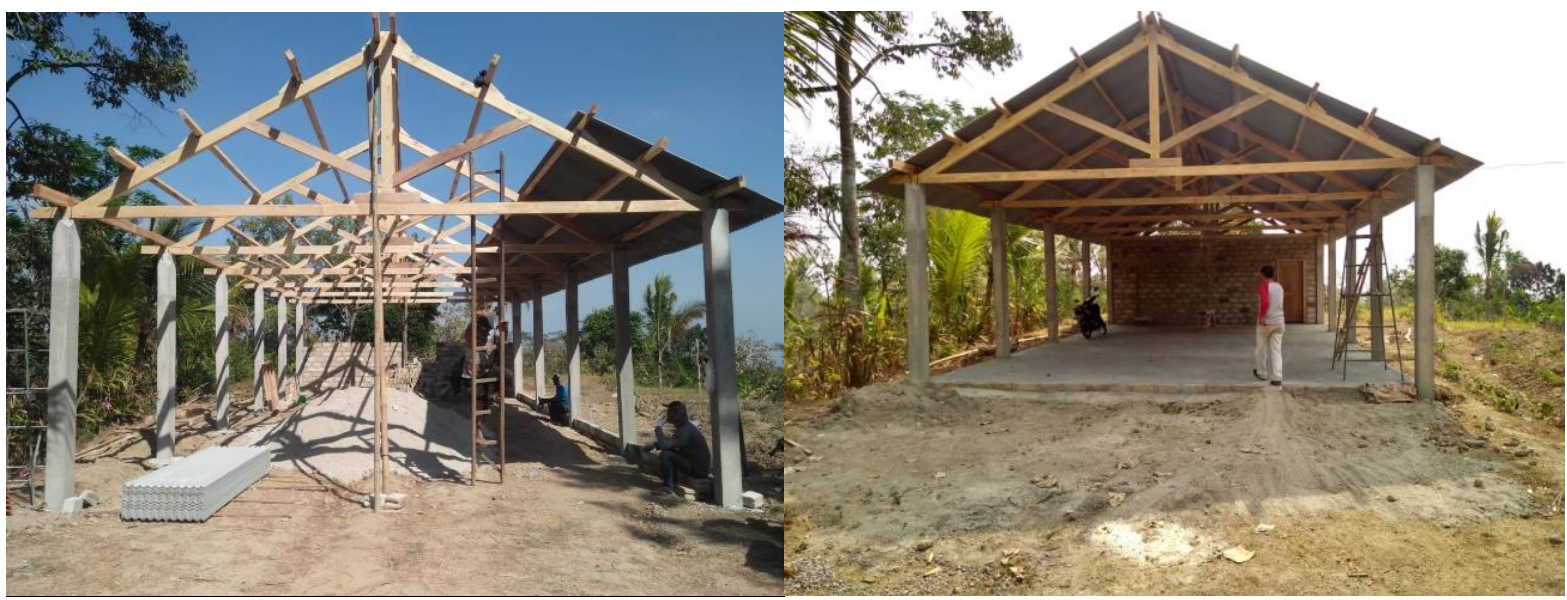




\section{Gambar 8. Penyelesaian Pembangunan Rumah Kompos}

Tim melakukan pendampingan dalam training konversi limbah kulit durian menjadi pupuk organik di Kampung Durian. Melalui belajar bersama, kelompok tani dampingan belajar mengolah dengan memanfaatkan produk yang tidak terpakai, yakni limbah kulit durian untuk dibuat pupuk sehingga memiliki nilai ekonomis baru bagi para petani durian sekaligus menurunkan beban timbulan sampah dari limbah durian.

Mereka dikenalkan bahwa bahan dasar kulit durian yang tidak dimanfaatkan akan sangat berarti bagi para petani, apabila diolah dengan baik. Pengenalan pengolahan limbah kulit durian dimulai melalui tahapan mengumpulkan limbah kulit durian sebagai bahan dasar pupuk kompos, pengenalan berbagai alat dan bahan serta intruksi cara kerja konversi limbah durian menjadi pupuk dengan kualitas yang baik.

Setelah mengetahui alat dan bahan yang diperlukan, serta teknik pengolahannya, mereka mulai mempraktekkan pengolahan limbah durian menjadi pupuk kompos mulai dengan pengeringan kulit durian, penghancuran kulit durian dalam serpihan yang lebih kecil, membuat fermentasi serbuk kulit durian dengan bahan-bahan lainnya sesuai dengan formula agar pupuk kompos yang terfermentasi memiliki kualitas yang baik melalui teknik fermentasi limbah durian.

Kulit durian untuk pembuatan pupuk kompos dikumpulkan dari perkebunan di Kampung Durian, pasar buah sekitar Ngebel Ponorogo dan Madiun. Setelah itu dilakukan pencacahan dengan menggunakan mesin pencacah limbah kulit durian menjadi ukuran yang lebih kecil.

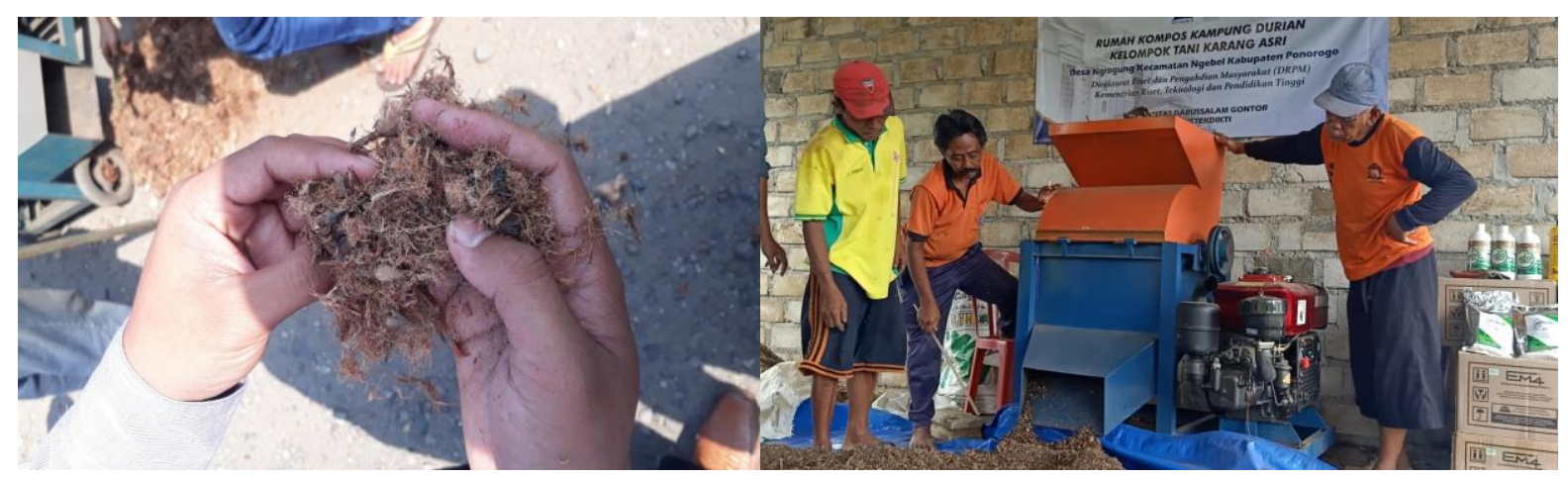

Gambar 9. Proses Pencacahan Kulit Durian Kering

Proses pengomposan ini dilakukan di rumah kompos Kampung Durian. Program peningkatan budidaya produksi dan kualitas buah durian dilakukan melalui pengembangan teknologi pengolahan pupuk limbah durian.

Pilihan menggunakan fermentasi untuk mengkonversi limbah kulit durian menjadi pupuk kompos bertujuan untuk meningkatkan nilai nutrisi yang prosesnya 
relatif mudah dan lebih mudah diberikan pada tumbuhan ${ }^{16}$. Penambahan substrat fermentasi baik secara langsung maupun tidak langsung merupakan salah satu metode yang dapat dilakukan guna meningkatkan kualitas hasil fermentasi17. Melalui fermentasi ini juga akan mampu mengurangi polusi sehingga diharapkan dapat menjaga efek keseimbangan ekologis ${ }^{18}$. Berikut langkah pembuatan kompos limbah durian yang disarikan dari beberapa referensi ${ }^{19,20,21}$ :

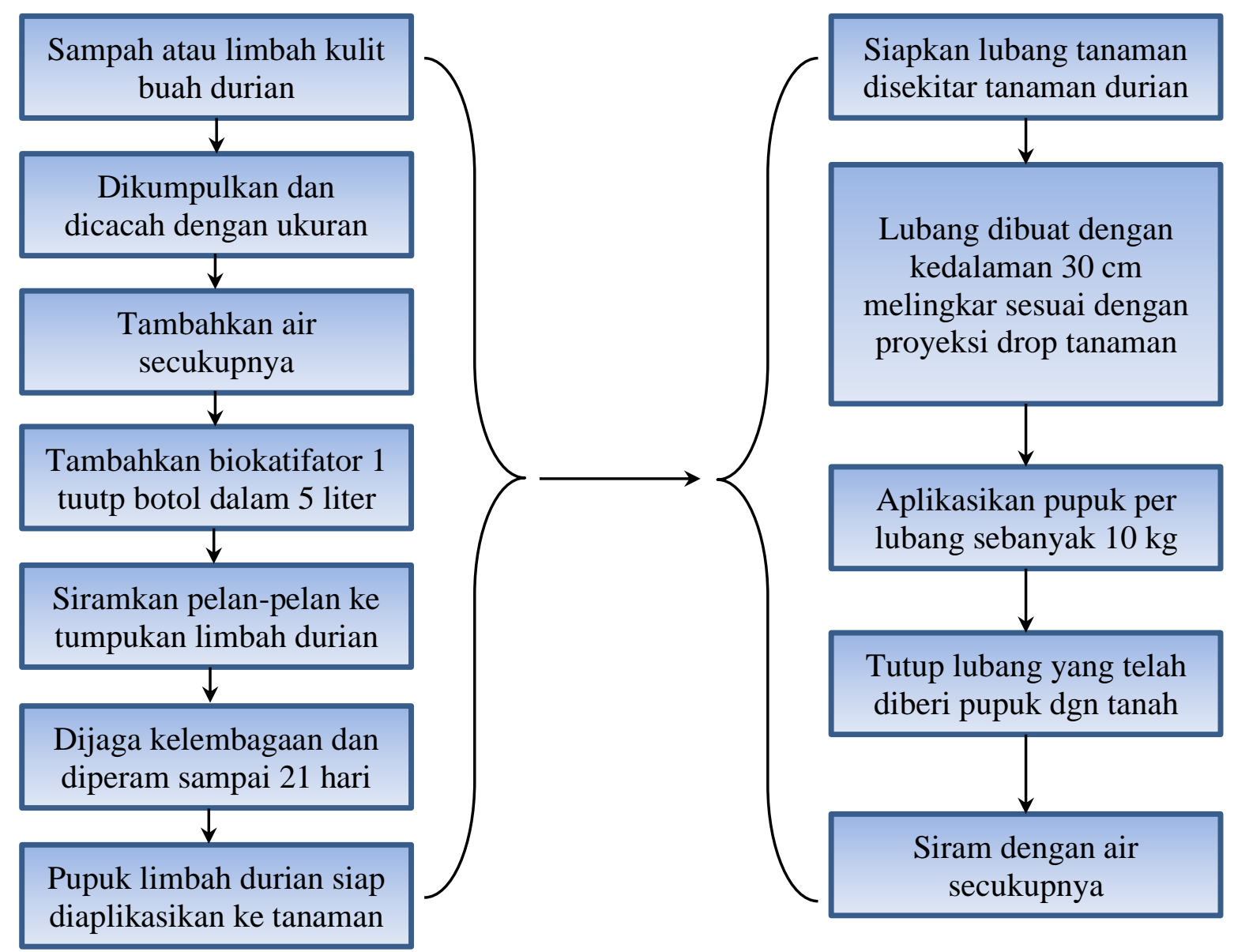

16 Jing-jing LIU et al., "The Effects of Fermentation and Adsorption Using Lactic Acid Bacteria Culture Broth on the Feed Quality of Rice Straw," Journal of Integrative Agriculture 14, no. 3 (2015): 503513.

17 Jian-Guo ZHANG, Hidenori Kawamoto, and Yi-Min CAI, "Relationships between the Addition Rates of Cellulase or Glucose and Silage Fermentation at Different Temperatures," Animal Science Journal 81, no. 3 (2010): 325-330.

18 Bing Bai, Chang-Guo Yan, and Guang-Chun Li, "Study on the Characteristics of Straw Fermentation by Bacillus Megaterium MYB3," Earth and Environmental Science 81, no. 1 (2017): 1-7.

19 Shaiful Rizal Masrol, Mohd Halim Irwan Ibrahim, and Sharmiza Adnan, "Chemi-Mechanical Pulping of Durian Rinds," Procedia Manufacturing 2 (2015): 171-180.

${ }^{20} \mathrm{~N}$ H Hasem et al., "Extraction and Partial Characterization of Durian Rind Pectin," in IOP Conference Series: Earth and Environmental Science, vol. 269 (IOP Publishing, 2019), 12019.

${ }^{21}$ T Arrizqiyani et al., "LC 50 of Rind Durian (Durio Zibethinus Murr) Extract to Mortality of Aedes Aegypti Larvae," in Journal of Physics: Conference Series, vol. 1179 (IOP Publishing, 2019), 12174. 


\section{Gambar 10. Pembuatan Kompos Limbah Durian}

Pendampingan rumah kompos sebagai fasilitas terpadu pengolahan pupuk organik di daerah sentra perkebunan Desa Ngrogung Ngebel Ponorogo berjalan dengan baik. Program pendampingan alih teknologi pengkomposan ini akan terus berlanjut di waktu mendatang. Sehingga kelomopk tani Karang Asri memiliki ketersedian pupuk organik untuk peningkatan budidaya produksi dan kualitas buah di Kampung Durian.

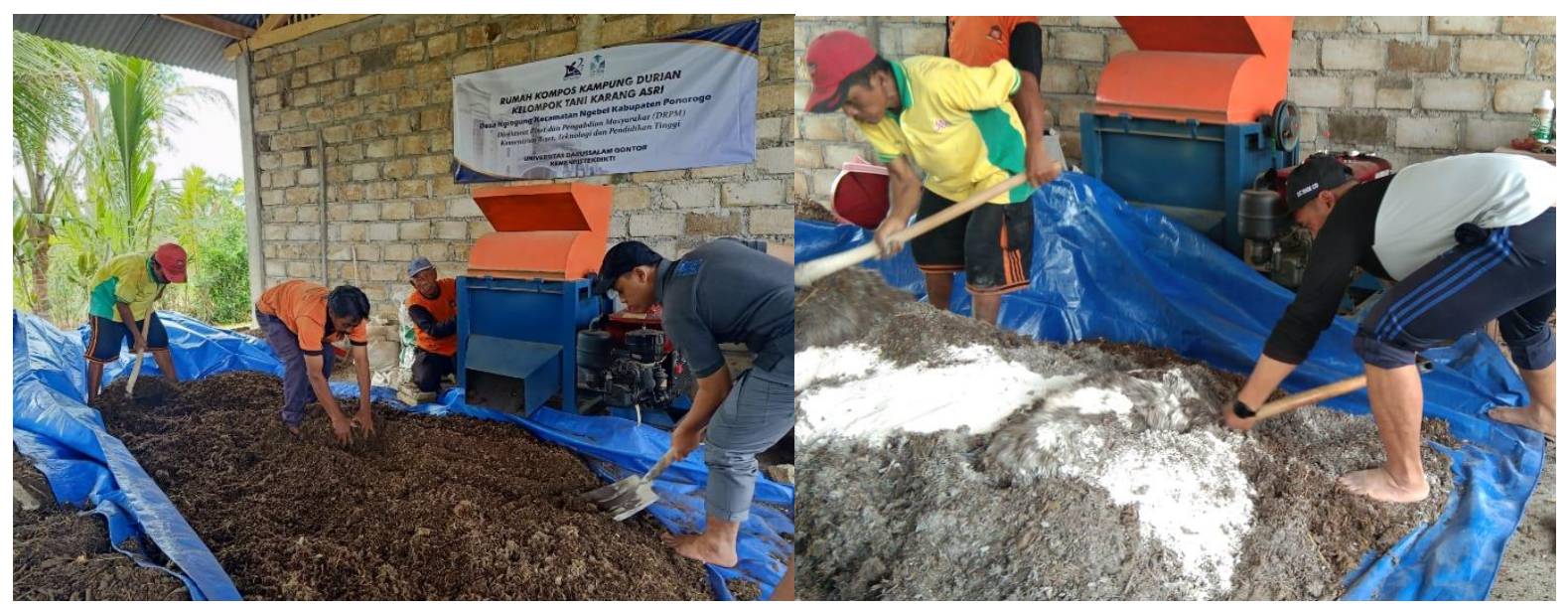

Gambar 11. Proses Pencampuran Limbah Durian Dengan Dolomit

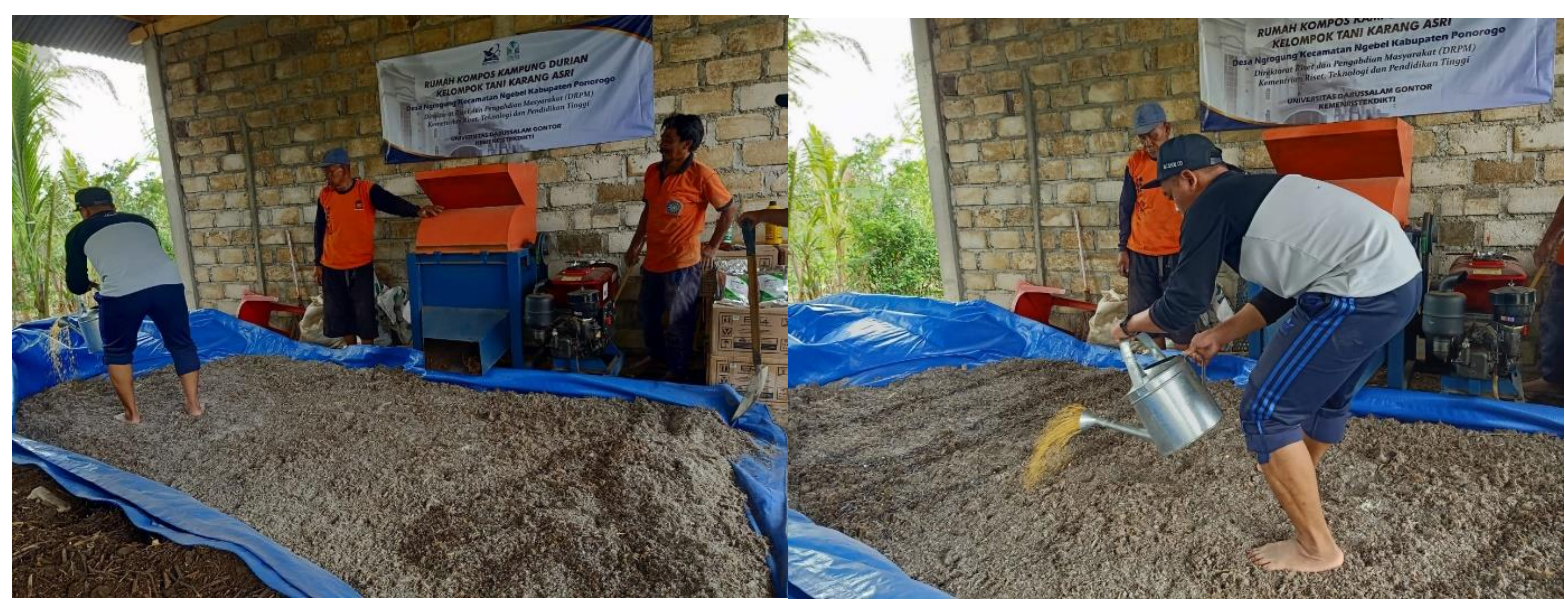

Gambar 12. Proses Pencampuran Limbah Durian Dengan EM4

Hasil jadi fermentasi dari konversi limbah kulit durian menjadi pupuk sudah bisa dipanen dan dimanfaatkan bagi para petani di Kampung Durian dan wilayah Ngebel Ponorogo. Hasil produk fermentasi limbah durian telah memiliki standar yang baik ditandai dengan tekstur pupuk yang bagus dan tidak ada pembusukan atau jamur, serta memiliki bau segar seperti pupuk kompos.

Tahap terakhir dalam pendampingan ini adalah refleksi yang menunjukkan hasil bahwa kelompok tani Karang Asri memiliki pengembangan peluang untuk mengelola limbah kulit durian menjadi pupuk kompos. Hasil produk ini telah diujicobakan ke mitra petani durian di wilayah Negbel. Respon petani mitra cukup baik, namun masih perlu 
diperkuat sinergi kemitraan antar kelompok tani yang ada di wilayah Kecamatan Ngebel, sehingga sirkulasi hasil produk lebih maksimal dan akan mampu mereduksi timbulan sampah kulit durian di Ponorogo.

Dampak hasil pendampingan ini memberikan alternatif bagi kelompok tani di Kampung Durian untuk membuka peluang usaha baru melalui pemanfaatan kulit durian menjadi pupuk kompos yang memiliki standar baik. Peluang ini sangat mungkin diwujudkan karena kelompok tani di Kampung Durian sudah memiliki modal sosial yang kuat dalam kewirausahaan sosial berbasis masyarakat, sehingga akan mampu menciptakan dan mengembangkan peluang-peluang usaha baru dari usaha wisata kuliner di Kampung Durian yang sudah menjadi usaha utama di Desa Ngrogung.

Hal ini memperkuat kajian dari Haris Setyaningrum ${ }^{22}$ dan Siti Noor Baya Binti Khalib $^{23}$ yang menyatakan bahwa model komposter mikro kulit durian di Kampung Durian, Ngrogung, Ponorogo, berhasil membentuk dan meningkatkan modal sosial masyarakat petani durian.

Modal sosial yang terbentuk saat ini memiliki pengaruh terhadap kewirausahaan sosial berbasis masyarakat sehingga mampu membangun kepercayaan antar pelaku usaha, adanya hubungan jaringan sebagai akses untuk pemecahan masalah, dan penerapan norma yang masih secara tradisional, serta mampu menciptakan lapangan pekerjaan baru bagi masyarakat setempat. Dampak ini akan mempengaruhi startegi pengembangan wisata Kampung Durian dan Telaga Ngebel yang menjadi ikon unggulan pariwisata di Ponorogo 24 .

Pendampingan ini juga menunjukkan bahwa petani durian didorong tidak hanya terfokus kepada produk utama mereka, namun juga mendorong agar para petani durian semakin mampu memanfaatkan sumberdaya alam yang ada di sekitarnya dengan bijak tanpa merugikan alam dan manusia, dan memiliki inisiatif untuk merubah barang tidak berharga menjadi barang bernilai guna untuk menghasilkan kebermanfaatan dan keuntungan bagi kelompok tani.

\section{Simpulan}

Ponorogo memiliki “Kampung Durian,” salah satu kawasan penghasil buah durian

22 Setyaningrum et al., "Durian Rind Micro Composter Model: A Case of Kampung Durian, Ngrogung, Ponorogo, Indonesia."

23 Siti Noor Baya Binti Khalib, Irnis Azura Binti Zakarya, and Tengku Nuraiti Binti Tengku Izhar, "Utilization of Rice Straw Ash during Composting of Food Waste at Different Initial C/N Ratios for Compost Quality," in IOP Conference Series: Materials Science and Engineering, vol. 551 (IOP Publishing, 2019), 12101.

24 Dhika Amalia Kurniawan and Mohammad Zaenal Abidin, "Strategi Pengembangan Wisata Kampoeng Durian Desa Ngrogung Kecamatan Ngebel Ponorogo Melalui Analisis Matrik IFAS Dan EFAS," Al Tijarah 5, no. 2 (2020): 93-103. 
terbesar di Kabupaten Ponorogo sehingga Kampung Durian menjadi destinasi wisata kuliner para penikmat durian di Ponorogo. Produksi durian yang besar di wilayah tersebut menimbulkan dampak timbulan sampah limbah kulit durian hingga ke Kawasan wisata Telaga Ngebel. Melalui pendampingan dengan pendekatan Asset Based Community Development (ABCD), tim pendamping bersama kelompok tani Karang Asri Kampung Durian Desa Ngrogung melakukan pengelolaan limbah kulit durian menajdi pupuk kompos sehingga memiliki nilai manfaat bagi petani sekaligus akan mampu menurunkan timbulan sampah di wilayah Ponorogo. Produk pupuk kompos sudah diuji cobakan ke mitra petani di perkebunan Kampung Durian bahkan di masyarakat sekitar wilayah Ponorogo sehingga mampu meringankan beban operasional pupuk tanaman yang dipikul para petani Kelompok Tani dan mampu mereduksi timbulan sampah kulit durian di Ponorogo. Dengan demikian, hasil dampingan ini menjadi salah satu solusi yang baik untuk mengelola limbah kulit durian dengan memperkuat peran kemitraan berbagai pihak, baik petani, akademisi dan regulator setempat..

\section{Ucapan Terima Kasih}

Ucapan terima kasih kami haturkan kepada Direktorat Riset dan Pengabdian Masyarakat (DRPM) Direktorat Jenderal Penguatan Riset dan Pengembangan Kementrian Riset, Teknologi, Dan Pendidikan Tinggi atas hibah pelaksanaan kegiatan pengabdian ini. Semoga hasil program ini dapat memberikan manfaat bagi petani durian di Kampung Durian khususnya dan Ponorogo.

\section{References}

Arrizqiyani, T, R Hidana, M A Sopian, and R Nurpalah. "LC 50 of Rind Durian (Durio Zibethinus Murr) Extract to Mortality of Aedes Aegypti Larvae." In Journal of Physics: Conference Series, 1179:12174. IOP Publishing, 2019.

Bai, Bing, Chang-Guo Yan, and Guang-Chun Li. "Study on the Characteristics of Straw Fermentation by Bacillus Megaterium MYB3." Earth and Environmental Science 81, no. 1 (2017): 1-7.

BPS Kab. Ponorogo. Kecamatan Ngebel Dalam Angka 2017. Kab Ponorogo: BPS Kab Ponorogo, 2017.

-——. Ponorogo Dalam Angka 2018. Kab Ponorogo: BPS Kab Ponorogo, 2018. https://ponorogokab.bps.go.id/ publication/2018/08/16/7400511f763983ffbab97edf/kabupaten-ponorogodalam-angka-2018.html. 


\section{7.}

Damanik, Volmer, Lahuddin Musa, and Posma Marbun. “Pengaruh Pemberian Kompos Kulit Durian Dan Kompos Kulit Kakao Pada Ultisol Terhadap Beberapa Aspek Kimia Kesuburan Tanah." Jurnal Agroekoteknologi Universitas Sumatera Utara 2, no. 1 (2013): 97671.

Handayani, Wiwik, and Sinta Dewi. "Pendampingan Pembuatan Pakan Ternak Dari Limbah Pembungkus Lontong Untuk Peningkatan Ekonomi Masyarakat Di Kelurahan Kupang Krajan Kecamatan Sawahan Kota Surabaya." Engagement: Jurnal Pengabdian Kepada Masyarakat 4, no. 2 (2020): 551-562.

Hasem, N H, S F Z Mohamad Fuzi, F Kormin, M F Abu Bakar, and S F Sabran. "Extraction and Partial Characterization of Durian Rind Pectin." In IOP Conference Series: Earth and Environmental Science, 269:12019. IOP Publishing, 2019.

Khalib, Siti Noor Baya Binti, Irnis Azura Binti Zakarya, and Tengku Nuraiti Binti Tengku Izhar. "Utilization of Rice Straw Ash during Composting of Food Waste at Different Initial C/N Ratios for Compost Quality." In IOP Conference Series: Materials Science and Engineering, 551:12101. IOP Publishing, 2019.

Khoiron, Khoiron, Ari Natalia Probandari, Wiwik Setyaningsih, Heru Subaris Kasjono, Roy Hendroko Setyobudi, and Olga Anne. "A Review of Environmental Health Impact from Municipal Solid Waste (MSW) Landfill." Annals of tropical medicine and public health 23, no. 3 (2020): 60-67.

Kinantan, Bag, A Rahim Matondang, and Juliza Hidayati. "Design of Integrated Waste Management Model of Medan City With Dynamic System Approach." In IOP Conference Series: Materials Science and Engineering, 505:12106. IOP Publishing, 2019.

Kurniawan, Dhika Amalia, and Mohammad Zaenal Abidin. "Strategi Pengembangan Wisata Kampoeng Durian Desa Ngrogung Kecamatan Ngebel Ponorogo Melalui Analisis Matrik IFAS Dan EFAS." Al Tijarah 5, no. 2 (2020): 93-103.

Kusumaningtyas, Ratna Dewi, Hardi Suyitno, and Ria Wulansarie. "Pengolahan Limbah Kulit Durian Di Wilayah Gunungpati Menjadi Biopestisida Yang Ramah Lingkungan." Rekayasa: Jurnal Penerapan Teknologi dan Pembelajaran 15, no. 1 (2018): 38-43.

LIU, Jing-jing, Xiao-ping LIU, Ji-wei REN, Hong-yan ZHAO, Xu-feng YUAN, Xiao-fen WANG, Abdelfattah Z M Salem, and Zong-jun CUI. "The Effects of Fermentation and Adsorption Using Lactic Acid Bacteria Culture Broth on the Feed Quality of Rice Straw." Journal of Integrative Agriculture 14, no. 3 (2015): 503-513.

Lubis, Rosliana, Basuki Wirjosentono, and Amanda Septevani. "Extraction and Characterization of Cellulose Fiber of Durian Rinds from North Sumatera as the Raw Material for Textile Fiber." In Journal of Physics: Conference Series, 1232:12017. IOP 
Publishing, 2019.

Masrol, Shaiful Rizal, Mohd Halim Irwan Ibrahim, and Sharmiza Adnan. "ChemiMechanical Pulping of Durian Rinds." Procedia Manufacturing 2 (2015): 171-180.

Mathie, Alison, and Gord Cunningham. "From Clients to Citizens: Asset-Based Community Development as a Strategy for Community-Driven Development." Development in practice 13, no. 5 (2003): 474-486.

McKnight, John. "Asset-Based Community Development: The Essentials." Chicago: AssetBased Community Development Institute (2017).

Penjumras, Patpen, Russly B Abdul Rahman, Rosnita A Talib, and Khalina Abdan. "Extraction and Characterization of Cellulose from Durian Rind." Agriculture and Agricultural Science Procedia 2 (2014): 237-243.

Setyaningrum, Haris, Atika Rukminastiti Masrifah, Adib Susilo, and Imam Haryadi. "Durian Rind Micro Composter Model: A Case of Kampung Durian, Ngrogung, Ponorogo, Indonesia." In E3S Web of Conferences, 226:21. EDP Sciences, 2021.

ZHANG, Jian-Guo, Hidenori Kawamoto, and Yi-Min CAI. "Relationships between the Addition Rates of Cellulase or Glucose and Silage Fermentation at Different Temperatures." Animal Science Journal 81, no. 3 (2010): 325-330. 